\title{
PENGARUH JARAK, KEMIRINGAN, DAN INTENSITAS CAHAYA PADA ANALISIS UKURAN PORI MASKER KAIN MENGGUNAKAN SMARTPHONE
}

\author{
Meri Hamdini, Diana Novita Sari, Susanti dan Yuant Tiandho* \\ ${ }^{1}$ Jurusan Fisika, Fakulas Teknik, Universitas Bangka Belitung,Kampus Terpadu UBB, Balunijuk, Kabupaten Bangka, 33172, Indonesia \\ *e-mail: yuant@ubb.ac.id
}

\begin{abstract}
ABSTRAK
Salah satu strategi umum yang digunakan untuk meminimalisir penyebaran Covid-19 adalah dengan memakai masker kain. Masker kain memiliki nilai efektivitas yang lebih kecil dibandingkan dengan masker medis namun berpotensi untuk dijadikan alternatif terutama selama pandemi. Smartphone dengan bantuan aplikasi perbesaran yaitu Magnifier Zoom Microscopedapat digunakan sebagai ide awal untuk penentuan kualitas dari suatu masker kain.Dalam pengambilan citra pori, terdapat faktor yang berpotensi mempengaruhi hasil ukuran pori yaitu jarak, sudut kemiringan, dan intensitas cahaya.Pengambilan foto masker dengan aplikasi perbesaran dilakukan dengan tiga variasi yaitu jarak, sudut, dan intensitas cahaya. Jarak pengambilan citra pori divariasikanmenjadi 3, yaitu $8 \mathrm{~cm}$; $10 \mathrm{~cm}$; dan $12 \mathrm{~cm}$. Sudut pengambilan citra divariasikan menjadi $0^{\circ}$; $5^{\circ}$; dan $10^{\circ}$, Pngukuran menggunakan jarak $10 \mathrm{~cm}$ memiliki nilai yang paling mendekati dari hasil pengukuran dengan pengambilan citra menggunakan mikroskop yaitu $0.232 \mathrm{~mm}$. Pada variasi sudut, sudut yang sejajar atau membentuk $O^{\circ}$ terhadap bidang masker kain memiliki nilai yang mendekati pengukuran mikroskop yaitu 0.232 mm. Intensitas cahaya yang diukur menggunakan lux meter yang menunjukan hasil 240 memiliki nilai yang paling mendekati pengambilan citra menggunakan mikroskop yaitu 0.221 mm.Ketiga variasi yang dilakukanmenunjukani bahwa jarak, derajat kemiringan, dan intensitas cahaya mempengaruhi hasil analisis citra.
\end{abstract}

Kata Kunci: Covid-19; Masker kain; Mikroskop; Ssmartphone.

ABSTRACT

[Title: Effect of Distance, Slope, and Light Intensity on Pore Size Analysis of Fabric Mask Using Smartphone] One of the common strategies used to minimize the spread of Covid-19 is wearing a cloth mask. Cloth masks have a lower effectiveness value compared to medical masks butcan be used as an alternative, especially during a pandemic. Smartphone with the help of application, namely Magnifier Zoom Microscopecan be used as an initial idea for determining the quality of a cloth mask. In taking pore images, there are factors thatcan affect the results of pore size, namely distance, angle of inclination, and light intensity. Taking photos of masks with a magnification application is done in three variations, namely distance, angle, and light intensity. The distance for taking pore images is varied to 3, namely $8 \mathrm{~cm} ; 10 \mathrm{~cm}$; and $12 \mathrm{~cm}$. The image capture angle is varied to $0^{p} ; 5^{\circ}$; and $10^{\circ}$. The measurement at a distance of 10 $\mathrm{cm}$ has the closest value from the measurement results by taking images using a microscope, which is $0.232 \mathrm{~mm}$. In the variation of the angle, the angle that is parallel or $0^{\circ}$ to the plane of the cloth mask has a value that is close to the microscope measurement, which is 0.232 $\mathrm{mm}$. The light intensity measured using a lux meter which shows the results of 240 has a value that is closest toan image taken with a microscope,namely $0.221 \mathrm{~mm}$. The three variations performed show that distance, angle, and light intensity affect the results of image analysis.

Keywords: Covid-19; Cloth mask; Microscope; Smartphone.

\section{PENDAHULUAN}

Coronavirus Disease atau yang lebih dikenal dengan Covid-19 merupakan penyakit yang menyerang sistem pernafasan manusia. Virus penyebab penyakit ini muncul di akhir tahun 2019 yang hingga saat ini masih menjadi masalah global (Sunjaya, et al., 2020). Penyebaran Covid-19 dikategorikan sebagai penyakit yang mudah menular yaitu melalui droplet yang mengandung virus sebagai jalur utama dengan daya penularannya yang tinggi (Sunaryo, 2020). Salah satu strategi umum yang digunakan untuk meminimalisir penyebaran Covid19 adalah dengan memakai masker. Pemakaian masker merupakan solusi bagi masyarakat untuk mencegah partikel udara seperti debu dan organisme biologis seperti virus dan bakteri masuk ke dalam tubuh manusia melalui hidung dan mulut (Tcharkhtchi, et al. 2021).

Masker kain merupakan salah satu jenis masker yang penggunaannya masih diperdebatkan dikarenakan efektivitasnya yang lebih kecil dibandingkan dengan masker jenis lain namun 
berpotensi untuk dijadikan alternatif terutama selama pandemi (Chungthai, et al. 2020). Masker kain memiliki kelebihan yaitu mudah didapatkan, ekonomis, dan sustainable (Esposito, et al. 2020).

Kualitas dari sebuah masker kain umumnya dipengaruhi oleh sifat bahan kain seperti porositas, pengepakan benang, dan ukuran pori (Neupane, Chaudhary dan Sharma 2020). Pencucian masker kain sebelum digunakan kembali menyebabkan peningkatan ukuran pori sehingga berpotensi menurunkan kualitas dan efisiensi filtrasi (Santos, et al. 2020).

Ketidakpastian efektivitas dari setiap masker kain umumnya dikarenakan produksinya menggunakan bahan yang berbeda sehingga menghasilkan ukuran pori yang beragam menjadikan pengukuran pori suatu masker kain penting untuk dilakukan. Pemanfaatan aplikasi pengolah citra yaitu ImageJ dapat digunakan sebagai ide awal untuk penentuan kualitas dari suatu masker kain.

ImageJ sdalah salah satu program analisis citra yang berbasis java yang mudah untuk digunakan dalam penentuan berbagai parameter ukuran citra (Ruaden, et al. 2017). Selain itu, ImageJ telah banyak dimanfaatkan di berbagai penelitian seperti perhitungan sel mikroba (Nichele, et al. 2020), analisis kekasaran permukaan besi (Budiana, et al. 2020), serta analisis ukuran partikel (Igathinathane, et al. 2008). Terlebih saat ini, penggunaan Image J dapat diakses secara online menjadikannya software pengolah citra yang potensial untuk digunakansecara luas.

Sebelum dapat dianalisis, terlebih dahulu dilakukan pengambilan citra pori menggunakan smartphone. Dalam pengambilan citra pori tersebut, terdapat faktor yang berpotensi mempengaruhi hasil ukuran pori yaitu jarak, sudut kemiringan, dan intensitas cahaya. Ketiga faktor tersebut merupakan faktor yang umumnya diabaikan namun akan berdampak pada hasil ukur sehingga mempengaruhi nilai akurasi pengukuran. Namun, pengkajian terkait ketiga faktor tersebut terhadap hasil analisis suatu citra masih minim dilakukan. Oleh karena itu, pada penelitian ini dilakukan analisis terkait pengaruh jarak, derajat kemiringan, dan intensitas cahaya terhadap hasil analisis citra.

\section{METODE}

Masker kain yang digunakan dalam penelitian ini merupakan salah satu masker yang dijual di Kota Pangkalpinang. Masker kain tersebut selanjutnya diambil citra porinya menggunakan mikroskop dan kamera smartphone dengan memanfaatkan aplikasi perbesaran. Aplikasi yang digunakan pada penelitian adalah Magnifier Zoom Microscope agar dapat dilakukan perbesaran hingga 10 kali. Pengambilan foto masker dengan aplikasi perbesaran dilakukan dengan tiga variasi yaitu jarak, sudut, dan intensitas cahaya. Jarak pengambilan citra pori di variasikan menjadi 3 , yaitu $8 \mathrm{~cm} ; 10 \mathrm{~cm}$; dan $12 \mathrm{~cm}$. Sudut pengambilan citra divariasikan menjadi $0^{\circ} ; 5^{\circ}$; dan $10^{\circ}$. Guna diperoleh pori secara jelas maka pada bagian belakang masker di sinari dengan cahaya. Selanjutnya citra atau foto yang diperoleh dianalisis dengan menggunakan software ImageJ. Pengukuran pori yang menggunakan mikroskop diukur secara manual pada ImageJ sedangkan pengukuran pori yang diambil menggunakan kamera dianalisis dengan metode otsu thresholding. Selanjutnya, data pengukuran yang dihasilkan dari masing-masing variasi dibandingkan dengan pengukuran menggunakan mikroskop untuk menentukan kesesuaian dan keakuratan nilai yang diperoleh.

\section{HASIL DAN PEMBAHASAN}

Kondisi pengambilan suatu citra menjadi salah satu faktor yang paling banyak diabaikan namun kenyataannya mampu mempengaruhi hasil dari suatu analisis citra. Beberapa faktor yang mempengaruhi hasil analisis citra terkait proses pengambilan citra adalah jarak, sudut, dan intensitas cahaya. Pengambilan citra pori masker menggunakan dua perangkat yaitu mikroskop dan sebuah aplikasi perbesaran.

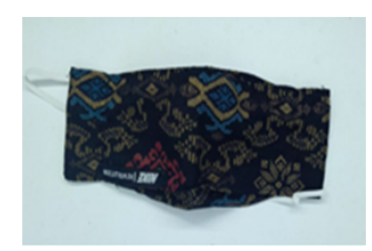

(a)

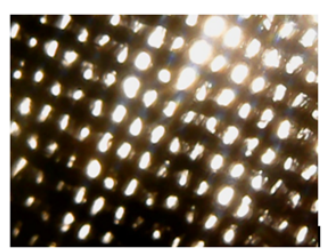

(b)
Gambar 1. (a) Masker Kain, (b) Citra Pori Masker Kain Menggunakan Mikroskop

Berdasarkan gambar $1 \mathrm{~b}$, tampak terlihat jelas citra dari pori dan serat dari masker kain yang menjadi objek analisis. Citra pori hasil mikroskop dianalisis secara manual menggunakamageJ dan dijadikan sebagai pembanding dalam pengukuran masker kain yang citranya diambil menggunakan aplikasi perbesaran dengan berbagai variasi kondisi.

Hasil citra pori masker kain yang diambil menggunakan aplikasi perbesaran tidak menunjukan serat yang tampak lebih jelas dibandingkan dengan menggunakan mikroskop, namun tetap dapat menghasilkan gambar pori yang jelas. 


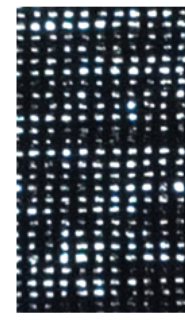

(a)

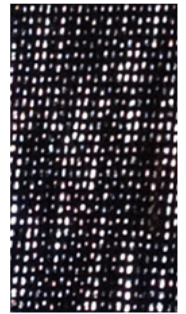

(b)

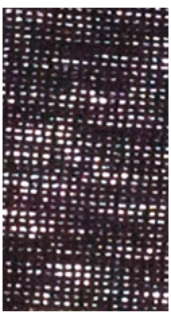

(c)

Gambar 2. Citra Pori Masker Kain Menggunakan Aplikasi Perbesaran denganVariasi Jarak (a) $8 \mathrm{~cm}$, (b) $10 \mathrm{~cm}$, dan (c) $12 \mathrm{~cm}$.

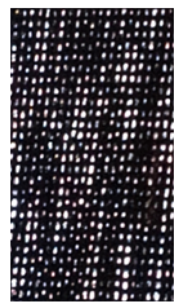

(a)

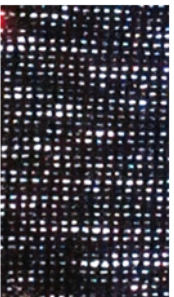

(b)

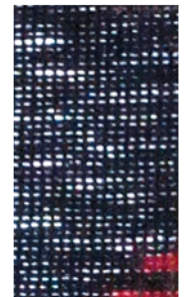

(c)

Gambar 3. Citra Pori Masker Kain Menggunakan Aplikasi Perbesaran dengan Variasi Sudut (a) $0^{\circ}$, (b) $5^{\circ}$, dan (c) $10^{\circ}$

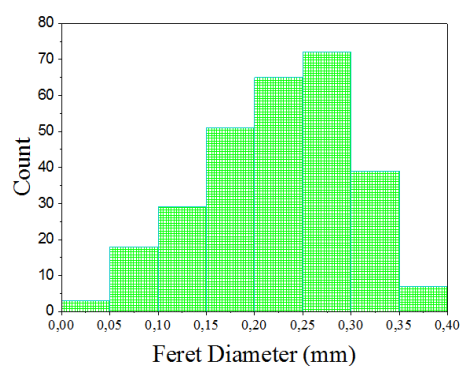

(a)

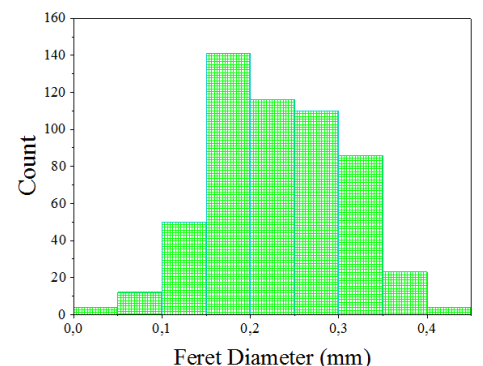

(b)

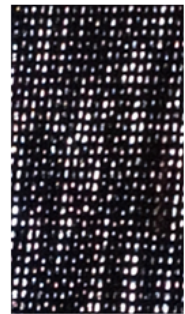

(a)

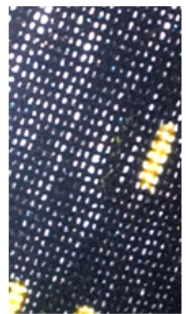

(b)

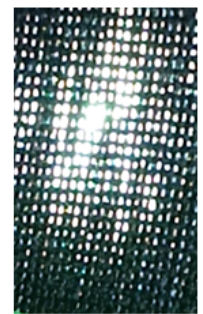

(c)

Gambar 4. Citra Pori Masker Kain Menggunakan Aplikasi Perbesaran dengan Variasi Intensitas Cahaya (a) 136, (b) 240, dan (c) 491

Dari ketiga variasi, perubahan yang tampak jelas selain dari banyak tidaknya pori masker adalah terjadinya perubahan warna, luasan citra, serta mampu menghasilkan cahaya tambahan pada permukaan citra yang tentunya perubahan tersebut akan mempengaruhi hasil analisis citra.

Gambar 5. Distribusi Diameter Feret Pori Masker dengan Variasi Jarak (a) $8 \mathrm{~cm}$, (b) $10 \mathrm{~cm}$, dan (c) $12 \mathrm{~cm}$

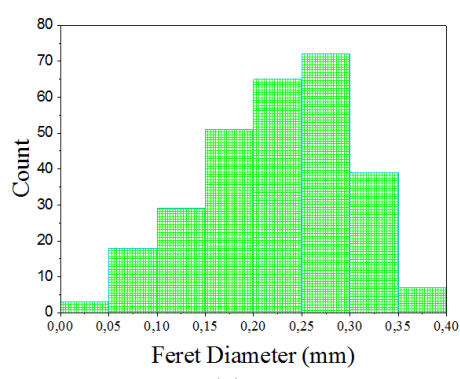

(a)

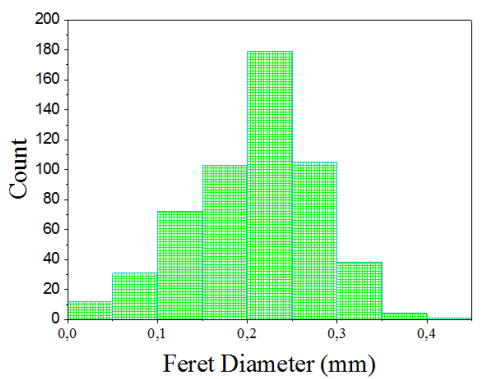

(b)

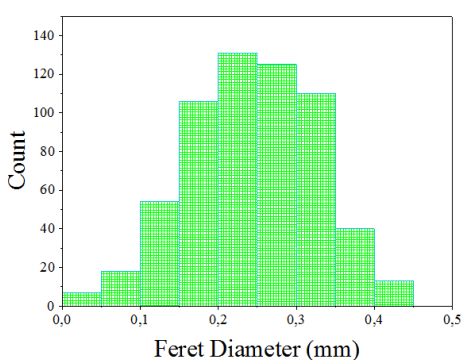

(c)

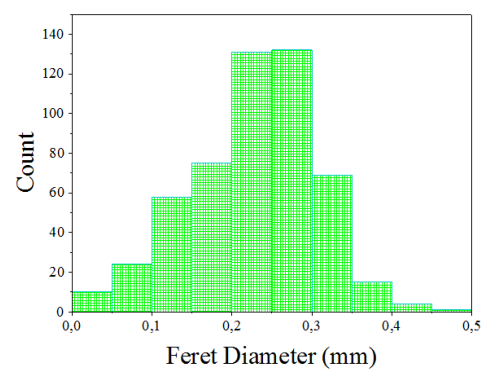

(c)

Gambar 6. Distribusi Diameter Feret Pori Masker dengan Variasi Sudut (a) $0^{\circ}$, (b) $5^{\circ}$, dan (c) $10^{\circ}$ 


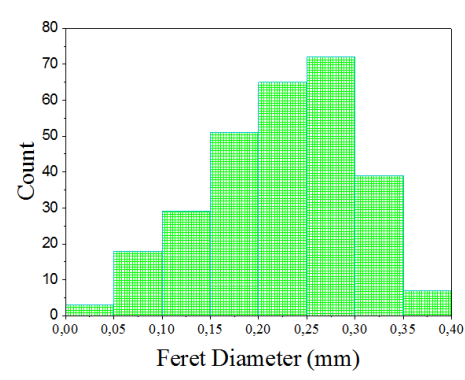

(a)

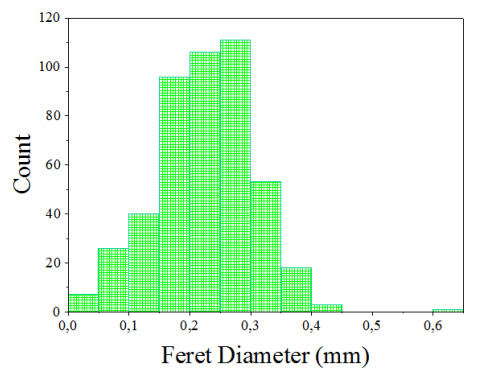

(b)

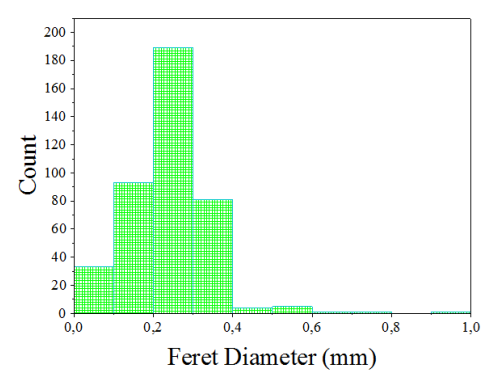

(c)

Gambar 7. Distribusi Diameter Feret Pori Masker dengan Variasi Intensitas Cahaya (a) 136, (b) 240, dan (c) 491

Distribusi diameter Feret masing-masing variasi pengukuran seperti ditunjukkan pada gambar 5, 6, dan 7 menunjukan hasil yang berbeda. Hal ini menunjukan bahwa masing-masing variasi akan menghasilkan nilai yang berbeda-beda.

Tabel 1. Nilai Rata-rata Diameter Feret Pori Masker Kain

\begin{tabular}{cc}
\hline Pengukuran & Mean $(\mathbf{m m})$ \\
\hline Mikroskop & 0.218 \\
Variasi Jarak & \\
$8 \mathrm{~cm}$ & 0.250 \\
$10 \mathrm{~cm}$ & 0.232 \\
$12 \mathrm{~cm}$ & 0.244 \\
Variasi Sudut $^{\circ}$ & \\
$5^{\circ}$ & 0.232 \\
$10^{\circ}$ & 0.240 \\
136 & 0.192 \\
240 & \\
491 & 0.232 \\
\hline
\end{tabular}

Diameter Feret merupakan sebuah parameter ukuran partikel yang secara sederhana didefinisikan sebagai jarak dua titik terjauh suatu bentuk dari sebuah partikel/benda yang pada penelitian ini adalah pori masker kain. Berdasarkan tabel 1 pengukuran dengan pengambilan citra menggunakan mikroskop menunjukkan nilai rata-rata ukuran diameter Feret pori sebesar 0,218 mm.

Berdasarkan penelitian yang telah dilakukan, menunjukkan bahwa pengaruh jarak pengambilan objek yang optimal adalah jarak $10 \mathrm{~cm}$ dengan nilai yang didapat paling mendekati pengukuran menggunakan mikroskop.

Pengukuran dengan sudut $0^{\circ}$ memiliki nilai yang paling mendekati nilai pengukuran menggunakan mikroskop. Kemiringan $0^{\circ}$ dikatakan merupakan posisi yang ideal untuk pengambilan citra dimana pada posisi tersebut arah kamera sejajar dengan permukaan pori masker kain.
Intensitas cahaya merupakan faktor lingkungan yang berpotensi mempengaruhi hasil pengambilan citra pori. Intensitas cahaya pada penelitian ini diukur menggunakan aplikasi lux meter. Lux meter yang menunjukan nilai 136 diambil dalam suatu ruangan tertutup tanpa penyalaan lampu namun tetap memiliki sedikit cahaya, nilai 240 diambil dalam ruangan dengan kondisi lampu menyala, sedangkan nilai 491 diambil di ruangan terbuka. Lux meter yang menunjukan nilai 240 memiliki nilai yang paling mendekati pengukuran menggunakan mikroskop yaitu 0.221 .

\section{KESIMPULAN DAN SARAN}

Berdasarkan ketiga variasi dengan tiga kondisi yang dilakukan diketahui bahwa ketiga faktor tersebut mempengaruhi hasil analisis citra. Pengukuran menggunakan jarak $10 \mathrm{~cm}$ memiliki nilai yang paling mendekati dari hasil pengukuran dengan pengambilan citra menggunakan mikroskop yaitu $0.232 \mathrm{~mm}$. Pada variasi sudut, sudut yang sejajar atau membentuk $0^{\circ}$ terhadap bidang masker kain memiliki nilai yang mendekati pengukuran mikroskop yaitu $0.232 \mathrm{~mm}$. Intensitas cahaya yang diukur menggunakan lux meter yang menunjukan hasil 240 memiliki nilai yang paling mendekati pengambilan citra menggunakan mikroskop yaitu $0.221 \mathrm{~mm}$. Pengkajian pengaruh kondisi seperti jarak, derajat kemiringan, dan intensitas cahayadalam pengambilan citra suatu pori perlu dilakukan guna diperoleh informasi yang lebih relevan.

\section{UCAPAN TERIMAKASIH}

Ucapan terimakasih penulis sampaikan kepada Kementerian Pendidikan, Kebudayaan, Riset dan Teknologi dalam Program Kreativitas Mahasiswa (PKM-RE) tahun 2021 yang telah mendanai penelitian ini.

\section{DAFTAR PUSTAKA}

Budiana, B., Nakul, F., Wivanius, N., Sugandi, B., Yolanda, R., Aminullah, D., et al. 2020. 
Analisis Kekasaran Permukaan Besi ASTM36 dengan Menggunakan Surfest dan Image-J. Journal of Applied Electrical Engineering, 4 (2): 49-54.

Chungthai, A., Seale, H., \& Macintyre, C. 2020. Effectiveness of Cloth Masks for Protection Against Severe Acute Respiratory Syndrom Coronavirus 2. Emerging Infectious Diseases, 26 (10): 1-5.

Esposito, S., Principi, N., Leung, C., \& Migliori, G. 2020. Universal Use of Face Masks for Success Againts COVID-19: Evidence and Implications for Preventing Policies. European Rspiratory Journal, 55 (6): 1-5.

Igathinathane, C., Pordesimo, L., Columbus, E., Batchelor, W., \& Methuku, S. 2008. Shape Identification and Particles Size Distributon from Basic Shape Parameters Using ImageJ. Computers and Electronics in Agriculture, 63: 168-182.

Neupane, B., Chaudhary, R., \& Sharma, A. 2020. A Smartphone Microscopic Method for Rapid Screening of Cloth Facemask Fabrics During Pandemics. PeerJ, 8: 1-11.

Nichele, L., Persichetti, V., Lucidi, M., \& Cincotti, G. 2020. Quantitative Evaluation of ImageJ Thresholding Algorithms for microbial Cell Counting. OSA Continuum, 3 (6): 14171427.

Ruaden, C.T, Schindelin, J., Hiner, M.C, DeZonia, B.E, Walter, A.E, Arena, E.T, Eliceiri, K.W. 2017. ImageJ2: ImageJ for the Next Generation of Scientific Image Data. BMC Bioinformatics, 18 (1): 1-26.

Santos, M., Torres, D., Cardoso, P., Pandis, N., Flores-Mir, C., Medeiross, R., and Normando, A.D. 2020. Are Cloth Masks a Substitute to Medical Masks in Reducing Transmission and Contamination? A systematic Review. Brazilian Oral Research, 34: 1-17.
Sunaryo, D. 2020. Pembuatan Masker Kain Sebagai Pencegahan Penularan Virus serta Mengoptimalkan Pendapatan di Masa Pandemi Covid-19 bagi Masyarakat di Desa Sukaratu. Jurnal Abdidas, 1 (4): 183-192.

Sunjaya, A., \& Morawska, L. 2020. Evidence Review and Practice Recommendation on the Material, Design, and Maintenance of Cloth Masks. Disaster Medicine and Public Health Preparedness, 14 (5): 42-46.

Tcharkhtchi, A., Abbasnezhad, N., Seydani, M., Zirak, N., Farzaneh, \& Shirinbayan, M. (2021). An Overview of Filtration Efficiency Through the Masks: Mechanism of the Aerosols Penetration. Bioactive Material, 6: 106-122. 